The Cryosphere Discuss., doi:10.5194/tc-2016-101, 2016

Manuscript under review for journal The Cryosphere

Published: 24 May 2016

(c) Author(s) 2016. CC-BY 3.0 License.

\title{
Full-Stokes modeling of grounding line dynamics, ice melt and iceberg calving for Thwaites Glacier, West Antarctica
}

\author{
Hongju Yu ${ }^{1}$, Eric Rignot ${ }^{1,2}$, Mathieu Morlighem ${ }^{1}$, and Helene Seroussi ${ }^{2}$ \\ ${ }^{1}$ Department of Earth System Science, University of California, Irvine, Irvine, CA, USA \\ ${ }^{2}$ Jet Propulsion Labratory, California Institute of Technology, Pasadena, CA, USA
}

Correspondence to: Hongju Yu (hongjuy@uci.edu)

\begin{abstract}
Thwaites Glacier (TG), West Antarctica, has been losing mass and retreating rapidly in the past three decades. Here we present a two-dimensional, Full-Stokes (FS) modeling study of the grounding line dynamics and iceberg calving of TG. First, we compare FS with two simplified models, the higher-order (HO) model and the shallow-shelf approximation (SSA) model, to determine the impact of changes in ice shelf basal melt rate on grounding line dynamics. Second, we combine FS with the Linear Elastic Fracture Mechanics (LEFM) theory to simulate crevasse propagation and iceberg calving. In the first experiment, we find that FS requires basal melt rate consistent with remote sensing observations to reach steady state at TG's current geometry while $\mathrm{HO}$ and SSA require unrealistically high basal melt rate. The grounding line of FS is also more sensitive to changes in basal melt rate than HO and SSA. In the second experiment, we find that only FS can produce surface and bottom crevasses that match radar sounding observations of crevasse width and height. We attribute the difference to the non-hydrostatic conditions of ice near the grounding line, which facilitate crevasse formation and are not accounted for in HO and SSA. Additional experiments using FS indicate that iceberg calving is significantly enhanced when surface crevasses exist near the grounding line, when ice shelf is shortened, or when the ice shelf front is undercut. We conclude that FS yields substantial improvements in the description of ice flow dynamics at the grounding line under high basal melt rate and in constraining crevasse formation and iceberg calving.
\end{abstract}

\section{Introduction}

Thwaites Glacier (TG) is the second largest and broadest ice stream in the Amundsen Sea Embayment (ASE) sector of West Antarctica (Fig. 1). Recent observations have found significant thinning and retreat of this glacier (Rignot, 2001; Shepherd et al., 2002; Pritchard et al., 2009; Rignot et al., 2014). Its mass balance was $-34 \pm 16$ Gt/yr in 2007 and has been decreasing until present (Rignot, 2008; Shepherd et al., 2012; Mouginot et al., 2014). In addition, its grounding line has retreated up to $14 \mathrm{~km}$ from 1992 to 2011 (Rignot et al., 2014). The bed elevation of the vast majority of the drainage basin of TG is well below sea level and decreases further inland (Tinto and Bell, 2011; Rignot et al., 2014). Such a bed configuration is potentially unstable according to the marine ice sheet instability theory (Weertman, 1974; Hughes, 1981; Schoof, 2007). Even with the buttressing of its ice shelf, TG may still undergo a rapid collapse, some of which may already started (Parizek et al., 2013; Joughin et al., 2014). It is therefore essential to better understand its dynamics and potential impact on global sea level. 
The Cryosphere Discuss., doi:10.5194/tc-2016-101, 2016

Manuscript under review for journal The Cryosphere

Published: 24 May 2016

(c) Author(s) 2016. CC-BY 3.0 License.

The rapid retreat and mass loss of TG have been attributed to high basal melting and iceberg calving (Depoorter et al., 2013; Rignot et al., 2013). The strengthening and poleward shift of the westerly winds may have brought more warm Circumpolar Deep Water (CDW) toward the ASE than in the past (Spence et al., 2014), which increased basal melting and caused the ice shelf to thin and the grounding line to retreat (Joughin et al., 2012; Rignot et al., 2013). Large calving events have been observed near the grounding line by satellites and densely distributed crevasses have been revealed by ice radar sounders on the ice shelf of TG (Fig. 2, Gogineni (2012)). Both the retreat of grounding line and the shortening of ice shelf reduce ice shelf buttressing and facilitate further retreat (Jenkins et al., 2010; Jacobs et al., 2011; Docquier et al., 2014; MacGregor et al., 2012).

The grounding line region is key to the stability of marine-terminating glaciers, but it is difficult to simulate numerically because the sharp transition from grounded ice to floating ice involves a complex stress field (Vieli and Payne, 2005; Nowicki and Wingham, 2008; Favier et al., 2012). A Full-Stokes (FS) model is required in this region to capture the flow dynamics accurately (Durand et al., 2009b; Morlighem et al., 2010). Yet, most previous modeling studies of TG used simplified models (Parizek et al., 2013; Docquier et al., 2014; Joughin et al., 2014). Iceberg calving is another process that is difficult to simulate due to the absence of a universal calving law. Most previous studies of crevasse propagation follow the work of Nye (1957), where crevasse propagation is based on the balance between longitudinal stress and ice overburden pressure (Nick et al., 2013; Cook et al., 2014). Although this criterion helps reproduce ice front calving, it does not take into account the stress concentration at the crevasse tip. To simulate crevasse propagation at the rupture tip, it is necessary to use the linear elastic fracture mechanics (LEFM) theory (van der Veen, 1998a, b; Krug et al., 2014).

In this work, we present a Full-Stokes modeling study of the grounding line region of TG using the Ice Sheet System Model (ISSM) framework constrained by remote sensing observations (Larour et al., 2012). The model is conducted in 2D along a flowline of TG. In the first part, we compare the performance of FS with simplified models at reproducing the ice flow of TG near the grounding line. The basal melt rate is adjusted until the glacier achieves steady state conditions with its current geometry. The results are compared with basal melt rate calculated from mass conservation. We then compare the response of TG to enhanced basal melting with FS and simplified models. In the second part of the study, we combine FS with the LEFM theory to investigate crevasse propagation and iceberg calving. We compare the calving behavior of TG using different initial geometries. We conclude on the importance of using FS for modeling the grounding line dynamics and calving processes of TG.

\section{Data and Methods}

\subsection{Data}

We select a flowline at the center of the fast flow region of TG as shown in Fig. 1. The flowline is $238 \mathrm{~km}$ long with 38 $\mathrm{km}$ of floating ice tongue (Fig. 3). BEDMAP-2 is used for surface elevation, bathymetry, and bedrock elevation (Fretwell et al., 2013). On grounded ice, bed elevation from Bedmap2 is replaced by bed elevation computed from mass conservation (Morlighem et al., 2011, 2013). At the grounding line, the two datasets display some discrepancies of hundreds of meters, but 
The Cryosphere Discuss., doi:10.5194/tc-2016-101, 2016

Manuscript under review for journal The Cryosphere

Published: 24 May 2016

(c) Author(s) 2016. CC-BY 3.0 License.

not along the particular flowline that we selected. The ice temperature field is set to the steady-state temperature computed from the thermal model in ISSM (Larour et al., 2012). This thermal model is constrained by surface temperature from the regional atmospheric climate model RACMO2 (Lenaerts et al., 2012) and geothermal heat flux from Maule et al. (2005), and includes both conduction and advection processes (Morlighem et al., 2010; Seroussi et al., 2013). The ice surface velocity is from interferometric synthetic aperture radar (InSAR) data collected in 2008 (Rignot et al., 2011).

\subsection{Ice Flow Model}

This work is performed on a 2D flowband model. The velocity gradient across our selected flowline in the grounding line region is small, which implies a small lateral drag. The comparison of lateral drag, longitudinal drag, basal drag and driving stress is shown in Fig. 4. The lateral drag, longitudinal drag and driving stress are computed as in (Van der Veen and Whillans, 1996) from the velocity, geometry and temperature field that we use to initialize the model. The basal drag is computed using the inferred FS basal friction coefficient (Section 2.5). The results are smoothed to $5 \mathrm{~km}$ resolution to remove large spatial variations. From $30 \mathrm{~km}$ upstream of the grounding line to the ice front, the lateral drag is approximately $18 \%$ of the longitudinal drag and $20 \%$ of the basal drag over grounded ice. In the vicinity of grounding line, it is about $10 \%$ of the longitudinal drag. The longitudinal drag and basal drag also balance well with the driving stress in this region. Further upstream, the lateral drag is in the same magnitude of the longitudinal drag and the basal drag because of the convergence of ice, but the ice is slow compare to the grounding line region and its influence to grounding line dynamics is small. Therefore, we conclude that neglecting the lateral drag in our 2D model is not a major limitation.

For completeness, we summarize the basic equations used in our simulations. The ice is considered as an incompressible viscous material driven by gravity. The governing equations of this system are the conservation of momentum and mass:

$\nabla \cdot \boldsymbol{\sigma}+\rho_{i} \boldsymbol{g}=\mathbf{0}$

$\nabla \cdot \boldsymbol{v}=0$

where $\boldsymbol{\sigma}$ is the stress tensor, $\rho_{i}$ the ice density, $\boldsymbol{g}$ the gravitational acceleration and $\boldsymbol{v}$ the ice velocity. The deformation of ice under stress is described by the constitutive law:

$\boldsymbol{\sigma}^{\prime}=2 \mu \dot{\varepsilon}$

where $\boldsymbol{\sigma}^{\prime}=\boldsymbol{\sigma}+p \mathbf{I}$, is the deviatoric stress, $p$ the ice pressure, $\mathbf{I}$ the identity matrix, $\mu$ the ice viscosity and $\dot{\varepsilon}$ the strain rate tensor. The ice viscosity $\mu$ is non-linear and follows Glen's law (Glen, 1955):

$\mu=\frac{B}{2 \dot{\varepsilon}_{e}^{\frac{n-1}{n}}}$

where $B$ is the ice viscosity parameter, $\dot{\varepsilon}_{e}$ the effective strain rate and $n$ the Glen's law exponent. Here, $B$ is a function of ice temperature with value taken from Cuffey and Paterson (2010) and the Glen's law exponent $n$ is set to 3. 
The Cryosphere Discuss., doi:10.5194/tc-2016-101, 2016

Manuscript under review for journal The Cryosphere

Published: 24 May 2016

(c) Author(s) 2016. CC-BY 3.0 License.

For a 2D flowband model, with $x, z$ the horizontal and vertical directions, $u, w$ the horizontal and vertical velocities, respectively, the above equations can be rewritten as:

$$
\begin{aligned}
& \frac{\partial}{\partial x}\left(2 \mu \frac{\partial u}{\partial x}\right)+\frac{\partial}{\partial z}\left(\mu \frac{\partial u}{\partial z}+\mu \frac{\partial w}{\partial x}\right)-\frac{\partial p}{\partial x}=0 \\
& \\
& \frac{\partial}{\partial x}\left(\mu \frac{\partial u}{\partial z}+\mu \frac{\partial w}{\partial x}\right)+\frac{\partial}{\partial z}\left(2 \mu \frac{\partial w}{\partial z}\right)-\frac{\partial p}{\partial z}-\rho_{i} g=0 \\
& 5 \frac{\partial u}{\partial x}+\frac{\partial w}{\partial z}=0
\end{aligned}
$$

This set of equations is the 2D Full-Stokes model, which does not make any approximation on the stress field of the flowband but is computationally expensive. To reduce the computational cost, simplified models with approximations are developed.

There are two widely used simplified models. The first one is the higher-order (HO) model (Blatter, 1995; Pattyn, 2003), which assumes that the horizontal gradient of vertical velocity and the bridging effect are negligible (van der Veen and Whillans, 1989). The governing equations are therefore reduced to:

$\frac{\partial}{\partial x}\left(4 \mu \frac{\partial u}{\partial x}\right)+\frac{\partial}{\partial z}\left(\mu \frac{\partial u}{\partial z}\right)-\rho_{i} g \frac{\partial s}{\partial x}=0$

where $s$ is the ice surface elevation. The vertical velocity $w$ is decoupled from the system and is computed from incompressibility.

The second model is the Shallow-Shelf Approximation (SSA) model, which makes the further assumption that the vertical shear is negligible (MacAyeal, 1989). This leads to the following 1D model:

$\frac{\partial}{\partial x}\left(4 H \bar{\mu} \frac{\partial u}{\partial x}\right)-\rho_{i} g H \frac{\partial s}{\partial x}=0$

where $H$ is the ice thickness and $\bar{\mu}$ the depth-averaged viscosity.

At each time step, the geometry of the flowband is updated by a mass transport model based on mass conservation. For FS, the ice surface and ice shelf bottom are treated as two independent free surfaces and updated separately:

$20 \frac{\partial z_{j}}{\partial t}+u_{j} \frac{\partial z_{j}}{\partial x}-w_{j}=\dot{m}_{j}$

where the subscript $j$ refers to either the ice surface $(j=s)$ or the ice shelf bottom $(j=b)$ and $\dot{m}_{j}$ is either the surface mass balance $(j=s)$ or the basal melt rate $(j=b)$. In HO and SSA, only the ice thickness needs to be updated because the ice shelf is assumed to be in hydrostatic equilibrium:

$\frac{\partial H}{\partial t}+\nabla \cdot(H \overline{\boldsymbol{v}})=\dot{m}_{s}-\dot{m}_{b}$

where $\overline{\boldsymbol{v}}$ is the depth-averaged velocity.

In a flowband model, the convergence of ice from upstream to downstream needs to be taken into account to conserve mass. Here, we first calculate the ice mass flux along the flowline. Then, we add an artificial surface mass balance term, $\dot{m}_{a}$, to the original surface mass balance, $\dot{m}_{s}$, to ensure that the ice mass flux is constant from the inflow boundary to the grounding line. 
The Cryosphere Discuss., doi:10.5194/tc-2016-101, 2016

Manuscript under review for journal The Cryosphere

Published: 24 May 2016

(c) Author(s) 2016. CC-BY 3.0 License.

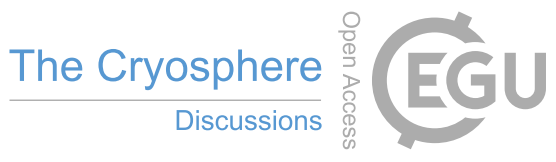

(c) (i)

\subsection{Boundary Condition}

At the ice surface, the atmospheric pressure exerted on ice is negligible and thus a stress free boundary condition is applied:

$\boldsymbol{\sigma} \cdot \mathbf{n}=0$

where $\mathbf{n}$ is the unit normal vector pointing outward.

5

At the bed, boundary conditions are different for grounded ice and floating ice. For grounded ice, the basal drag is assumed to follow a linear friction law:

$\tau_{\boldsymbol{b}}=-\alpha^{2} \boldsymbol{v}_{b}$

where $\tau_{\boldsymbol{b}}$ is the basal drag, $\boldsymbol{v}_{b}$ the velocity tangential to the bed and $\alpha$ the friction coefficient. Here, $\alpha$ is inferred from an inversion so that the modeled surface velocity matches observations (Section 2.5).

At the ice shelf bottom and at the ice front, seawater pressure is applied at the ice-ocean boundary:

$\begin{array}{ll}\boldsymbol{\sigma} \cdot \mathbf{n}=0 & z \geq 0 \\ \boldsymbol{\sigma} \cdot \mathbf{n}=\rho_{w} g z \mathbf{n} & z<0\end{array}$

where $\rho_{w}$ is the seawater density and sea level is at $z=0$. In our simulations, the ice shelf bottom elevation, $z_{b}(t)$, is unknown when applying this boundary condition. A replacement with $z_{b}(t-d t)$, with $d t$ the time step, produces large vertical velocities that destabilize the system (Durand et al., 2009a). A shelf dampening term based on ice velocity and geometry is therefore added to $z_{b}(t-d t)$ to approximate $z_{b}(t)$ :

$z_{b}(t)=z_{b}(t-d t)+\boldsymbol{v} \cdot \mathbf{n} \sqrt{1+\left(\partial z_{b}(t-d t) / \partial x\right)^{2}} d t$

At the inflow boundary, a Dirichlet boundary condition is applied for velocity. The horizontal velocity is taken from InSARderived ice velocity data (Rignot et al., 2011) and the vertical velocity is set to 0 .

\subsection{Grounding Line Migration}

The grounding line position is computed at every time step. The methods used to migrate the grounding line are different for FS and the simplified models. For FS, it is treated as a contact problem (Nowicki and Wingham, 2008; Durand et al., 2009b; Drouet et al., 2013). At each node on the ice-bedrock boundary, the normal stress exerted by the ice is compared to ocean water pressure. If the water pressure is higher than the normal stress, the corresponding node will be marked as floating and the grounding line will retreat. For the nodes at the ice-ocean boundary, a non-penetration condition is imposed. If the ice bottom elevation computed from the mass transport model is deeper than the bed elevation, the ice will reground and the grounding line will advance.

For HO and SSA, because the governing equations are simplified, the computed stress field cannot accurately represent the actual stress condition near the grounding line and the ice shelf has to be in hydrostatic equilibrium. Therefore, ice is floating 
The Cryosphere Discuss., doi:10.5194/tc-2016-101, 2016

Manuscript under review for journal The Cryosphere

Published: 24 May 2016

(c) Author(s) 2016. CC-BY 3.0 License.

if its thickness, $H$, is smaller than its floating height, $H_{f}$ :

$H_{f}=-\frac{\rho_{w}}{\rho_{i}} r_{f}$

where $r_{f}$ is the bedrock elevation. The grounding line position is at the location where $H=H_{f}$ (Seroussi et al., 2014).

\subsection{Inversion}

5 There is no direct observation of basal friction. In order to have a realistic representation of the basal conditions, we use an adjoint method, following Morlighem et al. (2010, 2013), to find a distribution of the basal friction coefficient, $\alpha$, that minimizes the cost function:

$\mathcal{J}(u, \alpha)=c_{1} \int_{\Gamma_{s}} \frac{1}{2}\left(u-u_{o b s}\right)^{2} d \Gamma+c_{2} \int_{\Gamma_{s}} \frac{1}{2} \ln \left(\frac{|u|+\epsilon}{\left|u_{o b s}\right|+\epsilon}\right)^{2} d \Gamma+c_{3} \int_{\Gamma_{b}} \frac{1}{2}\left(\frac{\partial \alpha}{\partial x}\right)^{2} d \Gamma$

where $u$ is the modeled surface velocity, $u_{o b s}$ the observed surface velocity, $\epsilon$ a minimum value $\left(10^{-8} \mathrm{~m} / \mathrm{yr}\right)$ to avoid zero velocity, $\Gamma_{s}$ and $\Gamma_{b}$ the ice surface and bedrock, respectively. The first term represents the misfit between modeled and observed velocity. The second term allows a better representation of slow regions and the third term is a Tikhonov regularization term to avoid short-scale variations of $\alpha$ (Vogel, 2002). The three parameters $c_{1}, c_{2}, c_{3}$ are tuned so that we obtain the best fit between modeled and observed surface velocity.

\subsection{Linear Elastic Fracture Mechanics Model}

A physically based LEFM model is used to simulate crevasse propagation. In the LEFM theory, there are three modes to open a crevasse: mode I opening, mode II sliding and mode III tearing. Only mode I is considered here. The key variables in the LEFM model are the stress intensity factor $K$ and fracture toughness $K_{c}$. If $K$ is larger than $K_{c}$, a crevasse will propagate. $K$ is computed through the integration of the normal stress from the bottom of the crevasse to the tip of the crevasse (van der Veen, 1998b). For bottom crevasses, we have:

$K=\int_{b}^{b+h} \frac{2 \sigma_{n}(z)}{\sqrt{\pi h}} G(z, h, H) d z$

$\sigma_{n}(z)=\sigma_{x x}(z)+\rho_{w} g z-\rho_{i} g(s-z)$

where $h$ is the height between the tip and the bottom of the crevasse, $b$ the elevation of the ice shelf bottom, $H$ the ice thickness, $\sigma_{x x}$ the longitudinal stress and $G$ a weighting function (Krug et al., 2014). For surface crevasses, the equations are similar with the water pressure term equals to zero. $K_{c}$ is a material property and previous studies showed that $K_{c}$ ranges from 0.1 to 0.4 $\mathrm{MPa} \mathrm{m}^{1 / 2}$ for ice (Fischer et al., 1995; Rist et al., 1996, 2002). Here, $K_{c}$ is set to $0.2 \mathrm{MPa} \mathrm{m}^{1 / 2}$, following Krug et al. (2014).

A simple algorithm for the combination of ISSM and the LEFM model is described in Fig. 5. First, an initial position for a crevasse to form is chosen arbitrarily. Then, ISSM is called to compute the stress field. With the stress field, the LEFM model is called to find the maximum height of the surface and bottom crevasses that satisfies $K>K_{c}$. The geometry is then updated 
The Cryosphere Discuss., doi:10.5194/tc-2016-101, 2016

Manuscript under review for journal The Cryosphere

Published: 24 May 2016

(c) Author(s) 2016. CC-BY 3.0 License.

to represent the propagation of crevasses. After that, the ice geometry is allowed to adjust with ISSM for a period of time, $0.01 \mathrm{yr}$ here, during which the crevasse becomes wider, shallower and smoother due to the viscous deformation of ice. Then the LEFM model is called again and we test if new crevasses can propagate at the center of the existing surface and bottom crevasses. Calving is assumed to occur when either the surface or the bottom crevasse reaches sea level (Benn et al., 2007).

\section{3 Simulations}

\subsection{Model setup}

ISSM is a coupled thermo-mechanical, finite element, ice flow model (Larour et al., 2012). The three models, FS, HO and SSA are all implemented in ISSM, which makes it a practical tool to compare their performance (Morlighem et al., 2010; Seroussi et al., 2011).

10 We choose a horizontal mesh resolution of $100 \mathrm{~m}$ to obtain a precise description of the grounding line position (Durand et al., 2009b). In the vertical direction, the domain is uniformly divided into 20 layers. In total, the mesh comprises 95,200 triangle elements. An inversion for the basal friction coefficient, $\alpha$, on grounded ice is first conducted for the selected flowline before any transient simulation is run.

\subsection{Basal Melting}

With no direct measurement of basal melt rate, the melt rate computed from mass conservation is used as an approximation of the actual basal melt rate, following Rignot et al. (2013). We take two flowlines that are $5 \mathrm{~km}$ apart on the ice shelf of TG, with the selected flowline in the center, and calculate the ice mass flux of this band from the grounding line to the ice front. Because the surface thinning rate and surface mass balance in this region is an order of magnitude smaller than the basal melt rate (Pritchard et al., 2009), the decrease of ice flux is assumed to be caused entirely by basal melting. The melt rate computed here is used as the control melt rate for the following experiments.

Once the control melt rate is computed, we find basal melt rate for each model that provide steady state solutions with the current geometry in a 100-yr simulation, with a time step of $0.1 \mathrm{yr}$. The basal melt rate is adjusted for each model to ensure that at the end of the simulation, the rate of thickness change is less than $0.05 \mathrm{~m} / \mathrm{yr}$, the grounding line does not migrate and the total change of ice shelf thickness is less than $25 \mathrm{~m}$ (Fig. 7b). We then compare the melt rate of each model with the control melt rate.

Two sets of sensitivity experiments are then conducted where we vary the basal melt rate (Table 1). In the first set, denoted Exp. Ma1-Ma4, we add an additional melt rate, $\dot{m}_{b_{-} a}$, to the control melt rate as a function of the depth of the ice shelf draft. We impose a maximum melt rate, $\dot{m}_{b 0}$, at $50 \mathrm{~m} / \mathrm{yr}, 100 \mathrm{~m} / \mathrm{yr}, 200 \mathrm{~m} / \mathrm{yr}$ and $300 \mathrm{~m} / \mathrm{yr}$, respectively, for Exp. Ma1-Ma4. $\dot{m}_{b_{-} a}$ is set to equal to $\dot{m}_{b 0}$ below $-600 \mathrm{~m}$, then linearly decreases to 0 at $-200 \mathrm{~m}$ and remains 0 above $-200 \mathrm{~m}$ (Fig. 8a). If the grounding line retreats, the basal melt rate applied on the ungrounded part is the control melt rate at current grounding line (68 $\mathrm{m} / \mathrm{yr}$ ) plus the additional melt rate $\dot{m}_{b_{-} a}$. 
The Cryosphere Discuss., doi:10.5194/tc-2016-101, 2016

Manuscript under review for journal The Cryosphere

Published: 24 May 2016

(c) Author(s) 2016. CC-BY 3.0 License.

In the second set, Exp. Mb1-Mb4, we use the basal melt rate that provides steady state for each model (Fig. 7) as the starting point. Then we add the same additional melt rate, $\dot{m}_{b_{-} a}$, as in Exp. Ma1-Ma4 (Fig. 9). To avoid a large region of over 500 $\mathrm{m} / \mathrm{yr}$ melt rate for SSA and HO, the melt rate applied for ungrounded region is altered. If the grounding line retreats, the melt rate from the new grounding line position to $38 \mathrm{~km}$ downstream is the initial melt rate along the $38 \mathrm{~km}$ ice shelf plus $\dot{m}_{b_{-} a}$ (Fig.

5 9). Further downstream, only $\dot{m}_{b_{-} a}$ is applied. The two sets of sensitivity experiments are both run for 40 years for each of the three models.

\subsection{Crevasse Propagation}

The propagation of crevasses takes place over small spatial and temporal scales. In order to increase the reliability of the model, the mesh is refined accordingly. The horizontal resolution is increased from $100 \mathrm{~m}$ to $5 \mathrm{~m}$ within $3 \mathrm{~km}$ of the initial crevasse position and the number of vertical layers is increased from 20 to 40 . The domain is therefore discretized into 281,660 elements. The time step is shortened from $0.1 \mathrm{yr}$ to $0.0005 \mathrm{yr}(\sim 4.4 \mathrm{hr})$ and the LEFM model is called every $0.01 \mathrm{yr}$. The simulations are run for $0.3 \mathrm{yr}$ or until calving occurs, whichever happens first.

Five sets of experiments, Exp. $\mathrm{Ca}-\mathrm{Ce}$, are conducted to simulate the propagation of crevasses (Table 1). In the first set, eleven experiments, Exp. Ca1-Ca11, are conducted with micro initial crevasses, which have both width and height initialized at 0 . In all experiments, the experiment number 1-11 indicates the initial crevasse position, respectively, at $0.5 \mathrm{~km}, 1 \mathrm{~km}, 1.5$ $\mathrm{km}, 2 \mathrm{~km}, 2.5 \mathrm{~km}, 3 \mathrm{~km}, 3.5 \mathrm{~km}, 18 \mathrm{~km}, 28 \mathrm{~km}, 35 \mathrm{~km}$ and $36 \mathrm{~km}$ downstream of the grounding line. These positions are chosen to represent the crevasse propagation near the grounding line, in the middle of the ice shelf and near the ice front.

In the following experiments, the initial geometry is altered to investigate the calving behavior in the grounding line region. In the second set (Exp. Cb1-Cb7), a $3 \mathrm{~m}$ deep, $100 \mathrm{~m}$ wide initial surface crevasse is added to the initial geometry while the initial bottom crevasses are still micro crevasses. The third (Exp. Cc1-Cc7) and fourth (Exp. Cd1-Cd3) sets are designed to test the stability of TG to a shortened ice shelf. In these two sets, the ice shelf length is shortened from $38 \mathrm{~km}$ to $4 \mathrm{~km}$ and 2 $\mathrm{km}$, respectively. In the last set (Exp. Ce1-Ce7), we add a $400 \mathrm{~m}$ wide and $400 \mathrm{~m}$ high undercutting at the ice front on the 4 $\mathrm{km}$ ice shelf case to investigate the impact of undercutting on calving.

\section{Results}

\subsection{Inversion}

Results from the inversion are shown in Fig. 6. For all three models, the inferred basal friction coefficient, $\alpha$, has similar values and spatial patterns. The modeled surface velocity after inversion closely matches observed surface velocity on grounded ice. There is still a $200 \mathrm{~m} / \mathrm{yr}$, or $6 \%$, difference in the grounding line region and on the ice shelf. We attribute this discrepancy to the errors in ice rheology field and the lack of lateral drag. Yet, all modeled ice surface velocities are in good agreement, which provides comparable initial conditions. 
The Cryosphere Discuss., doi:10.5194/tc-2016-101, 2016

Manuscript under review for journal The Cryosphere

Published: 24 May 2016

(c) Author(s) 2016. CC-BY 3.0 License.

\subsection{Basal Melting}

The melt rate computed from mass conservation is shown as "control" in Fig. 7a. It is highest within $10 \mathrm{~km}$ of the grounding line. The maximum occurs at $2.4 \mathrm{~km}$ downstream of the grounding line and reaches $73 \mathrm{~m} / \mathrm{yr}$. Further downstream of the grounding line, the melt rate oscillates around $10 \mathrm{~m} / \mathrm{yr}$ due to the spatial variations in the elevation of the ice shelf bottom.

The basal melt rate required for FS, HO and SSA to maintain steady state at the current geometry are plotted in Fig. 7a. For all three models, the melt rates are similar and match the control rate except the first $5 \mathrm{~km}$ of the ice shelf. Within $5 \mathrm{~km}$ of the grounding line, especially the first $3 \mathrm{~km}$, FS is different from HO and SSA. The FS result is similar to the control rate with a peak melt rate of $86 \mathrm{~m} / \mathrm{yr}$ at $2.5 \mathrm{~km}$ downstream of the grounding line, while the results of $\mathrm{HO}$ and SSA are unrealistically high: they both require over $500 \mathrm{~m} / \mathrm{yr}$ melt rates to prevent the grounding line from advancing (Fig. 7a). For FS, we find a 5 $\mathrm{km}$ zone downstream of the grounding line where the ice is below hydrostatic equilibrium. The deviation is of the order of tens of meters with a maximum of $68 \mathrm{~m}$ at $400 \mathrm{~m}$ downstream of the grounding line.

The results of the first set of the sensitivity experiments (Exp. Ma1-Ma4) are shown in Fig. 8. In the control run, the grounding line of FS is stable at its current position and the ice shelf thickens slightly. For HO and SSA, the grounding line positions advance by $3.6 \mathrm{~km}$ and $4.9 \mathrm{~km}$, respectively, and the ice shelf thickens by a few hundred meters. With enhanced basal melting compared to the control melt rate, the grounding line position of FS retreats by $42 \mathrm{~km}, 85 \mathrm{~km}, 120 \mathrm{~km}$ and $124 \mathrm{~km}$, respectively, for Exp. Ma1-Ma4. On the contrary, for HO and SSA, the grounding lines only retreat slightly in Exp. Ma4.

In the second set of experiments (Exp. Mb1-Mb4, Fig. 9), the grounding line retreats in every experiment for all models, as expected. However, the sensitivity of grounding line positions to changes in melt rate is different. In FS, the grounding line retreats by $73 \mathrm{~km}, 115 \mathrm{~km}, 123 \mathrm{~km}$ and $127 \mathrm{~km}$ for Exp. Mb1-Mb4, respectively. For HO and SSA, the grounding line retreat is the same for all four experiments, $37 \mathrm{~km}$ for $\mathrm{HO}$ and $21 \mathrm{~km}$ for SSA. In both sets of sensitivity experiments, along with the grounding line retreat, strong surface thinning and mass loss are produced in the entire domain for FS. However, despite the similarity in ice shelf thinning, the grounded ice thinned significantly less for HO and SSA.

To summarize, only FS can reach a steady state with realistic values of the magnitude of basal melting and capture the current grounding line position. The simplified models, HO and SSA, require high basal melt rates near the grounding line and are also less sensitive to changes in basal melt rate.

\subsection{Crevasse Propagation}

In all crevasse propagation experiments with $\mathrm{HO}$ and SSA, we find that the height of bottom crevasses never exceeds 50 $\mathrm{m}$, which is small compared to observations and does not grow enough to produce a calving event. In other words, if the assumption of hydrostatic equilibrium is used for the ice shelf, HO and SSA are unable to grow crevasses that can generate calving using the LEFM theory. In the remainder of the paper, we only discuss the FS case.

In the first set of experiments (Exp. Ca1-Ca11), based on the initial geometry and the introduction of micro crevasses at both the surface and the bottom of the ice shelf, the crevasses of all eleven cases stop growing at the end of the experiments and none of them produce calving (Fig. 10). The final height of bottom crevasses is 200-300 m near the grounding line (Exp. 
The Cryosphere Discuss., doi:10.5194/tc-2016-101, 2016

Manuscript under review for journal The Cryosphere

Published: 24 May 2016

(c) Author(s) 2016. CC-BY 3.0 License.

Ca1-Ca7) and 50-100 m downstream (Exp. Ca8-Ca11). The surface crevasses are one order of magnitude smaller, 10-15 m near the grounding line and 2-5 m downstream. The width of all crevasses is $400-500 \mathrm{~m}$.

The results of the experiments with varying initial geometry are shown in Fig. 11. In Exp. Cb1-Cb7, where we add a 3 $\mathrm{m}$ surface crevasse at the top of the ice shelf, calving occurs for crevasses located within $1.5 \mathrm{~km}$ of the grounding line (Exp.

$5 \mathrm{Cb} 1-\mathrm{Cb} 3$, Fig. 11a). Further downstream of the grounding line (Exp. Cb4-Cb7), the crevasse propagation is nearly identical to the case with micro initial surface crevasse (Exp. Ca4-Ca7), i.e. crevasse height does not exceed 200-300 m.

With an ice shelf shortened to a length of $4 \mathrm{~km}$, calving occurs within $1 \mathrm{~km}$ of the ice front (Exp. Cc6 and Cc7, Fig. 11b) and the other experiments (Exp. Cc1-Cc5) have results similar to the initial $38 \mathrm{~km}$ long ice shelf (Exp. Ca1-Ca5). With an ice shelf shortened to only $2 \mathrm{~km}$, calving occurs in all three experiments (Exp. Cd1-Cd3, Fig. 11c).

In the last set, the ice shelf is shortened and undercut. We find that calving occurs within $1.5 \mathrm{~km}$ of the ice front (Exp. Ce5-Ce7, Fig. 11d). In regions where calving does not occur, undercutting vanishes slowly within $0.1 \mathrm{yr}$ due to the viscous deformation and the downstream advection of ice.

In all of the above experiments, Exp. Cc6 produces calving caused by surface crevasse propagating to sea level and it takes approximately $0.24 \mathrm{yr}$ for the calving to occur. For all other cases, calving occurs because a bottom crevasse propagates to sea level and the process is significantly more rapid, within $0.05 \mathrm{yr}$.

\section{Discussion}

\subsection{Basal Melting}

Our results show that only FS experience significant grounding line migration and provides a realistic response to enhanced basal melting. With HO and SSA, the basal melt rates have to be unrealistically high near the grounding line, i.e. over 500 $\mathrm{m} / \mathrm{yr}$, in order for the models to achieve steady state conditions with the current geometry.

In the grounding line region, the abrupt change in boundary condition creates a singularity. Most importantly, ice is pushed below hydrostatic equilibrium downstream of the grounding line as a result of a bending moment of the ice. This bending moment does not exist in the simplified models. As a result of the non-hydrostatic conditions, the ice pressure and the vertical velocity are high, which produces high vertical shear stress that tends to lift the ice from the bed. FS is capable of taking into account this high vertical shear stress and makes it possible to migrate the grounding line based on realistic stress conditions. In $\mathrm{HO}$ and SSA, bridging effects are neglected and ice is assumed to be in hydrostatic equilibrium, which tend to make the grounding line advance.

Our sensitivity experiments show that the grounding lines in HO and SSA are much less sensitive to an increase in basal melt rate. In contrast, the FS grounding line is more sensitive to enhanced basal melting and retreats almost in every scenario. On

flat or retrograde bed, the migration of the grounding line is similar in all three models. Yet, on a prograde bed, the grounding lines of $\mathrm{HO}$ and SSA tend to sit on bedrock bumps unless unrealistic basal melt rate is applied at the grounding line (Fig. 8-9). To retreat over the bump where the current grounding line is at, over $500 \mathrm{~m} / \mathrm{yr}$ melt rate is required. Even $800 \mathrm{~m} / \mathrm{yr}$ melt rate is unable to make $\mathrm{HO}$ and SSA retreat over the bump $37 \mathrm{~km}$ and $21 \mathrm{~km}$ upstream of the current grounding line, respectively. 
The Cryosphere Discuss., doi:10.5194/tc-2016-101, 2016

Manuscript under review for journal The Cryosphere

Published: 24 May 2016

(c) Author(s) 2016. CC-BY 3.0 License.

However, satellites observations have shown that the grounding line of TG and its neighbor Pine Island Glacier has already retreated over a few bedrock bumps in the past decade under current ocean forcing (Rignot et al., 2014). This suggests that previous studies of TG may have underestimated its response to changes in ocean thermal forcing (Parizek et al., 2013; Joughin et al., 2014).

5 In the future, a steady increase in the strength of the westerlies may cause the ocean temperature to rise by more than $2^{\circ} \mathrm{C}$. It may also push more ocean heat toward TG without any changes in ocean temperature (Spence et al., 2014). As a result, the basal melting of TG will be enhanced. As the glacier is retreating into an area where the bed elevation is lower, the melt rate will be further increased because of the pressure-dependence of the melting point of the ocean water/ice melange. In Rignot and Jacobs (2002), it is suggested that a $1{ }^{\circ} \mathrm{C}$ increase in ocean thermal forcing would raise the basal melt rate by $10 \mathrm{~m} / \mathrm{yr}$. In Holland et al. (2008), the basal melt rate is suggested to increase quadratically to ocean warming. However, in either case, the basal melt rate of TG would be unlikely to increase by more than $100 \mathrm{~m} / \mathrm{yr}$. In our experiments as well as in previous studies, basal melt rate of at least $200 \mathrm{~m} / \mathrm{yr}$ have been required to push the grounding line out of equilibrium using $\mathrm{HO}$ and SSA (Parizek et al., 2013; Joughin et al., 2014). If we increase the basal melt rate by a more realistic $50 \mathrm{~m} / \mathrm{yr}$, our results suggest that only FS can produce a retreat of the grounding line (Exp. Ma1). Even if we use a high initial basal melt rate for $\mathrm{HO}$ and SSA, the response of grounding line to enhanced basal melting is still less sensitive and largely dependent on the bed topography (Exp. Mb1-M4b). We conclude that it may be essential to use FS in the grounding line region for 2D simulations to correctly represent the impact of ocean thermal forcing on grounding line stability.

\subsection{Crevasse Propagation}

The sizes of surface and bottom crevasses produced from our crevasse propagation experiments with FS (Fig. 10) are compatible with the size of surface and bottom crevasses observed from ice radar sounders (Fig. 2, Gogineni (2012)). This suggests that the combination of FS with the LEFM theory is a realistic tool to study crevasse propagation and iceberg calving. However, with HO and SSA, because of the assumption of hydrostatic equilibrium, the water pressure term and ice pressure term in Eq. (19) cancel out and thus the crevasses are unable to grow to a size that matches observations. In the radar echograms, large bottom crevasses are also observed along the ice shelf, tens of kilometers downstream of the grounding line. We think that these crevasses may be the result of advection of crevasses from upstream, not from a recent cracking.

In our simulations, we find that crevasses propagate significantly faster near the grounding line when they initiate from a 3-m deep surface crevasse. The existence of such a small crevasse has limited impact on the overall stress field of the ice shelf. The reason that it has an influence on crevasse propagation is that it changes the pressure field. At the ice bottom of the grounding line region, ice is pushed below hydrostatic equilibrium, the longitudinal stress field is small or even compressive. In the first few steps of the simulation, the bottom crevasse does not propagate. During that time, the surface crevasse grows because the surface longitudinal stress is large. The difference between water pressure and the overburden ice pressure keeps increasing at the bottom until the stress intensity factor of the bottom crevasse is larger than its fracture toughness. With an initial surface crevasse, the difference between water and ice pressure is enhanced and the bottom crevasse is then able to propagate through the entire ice thickness and produce calving. In the flowline selected here, we find that $3 \mathrm{~m}$ is the minimum initial surface 
The Cryosphere Discuss., doi:10.5194/tc-2016-101, 2016

Manuscript under review for journal The Cryosphere

Published: 24 May 2016

(c) Author(s) 2016. CC-BY 3.0 License.

crevasse depth that is required to produce calving. If the non-hydrostatic behavior of the ice is more pronounced, the required minimum height of the surface crevasse will become smaller.

In principle, the length of a non-confined ice shelf, such as the floating ice tongue of TG, should not have a major impact on the buttressing that the ice shelf exerts on grounded ice. Here, however, we find that the propagation of crevasse near the

5 ice front is limited on the initial $38 \mathrm{~km}$ ice shelf while it is significantly more likely to experience calving with a shortened ice shelf. When the ice shelf is shortened, the longitudinal stress near the ice front will increase at the surface and decrease at the bottom. The increase in the surface stress makes it easier for the surface crevasse to propagate, while the decrease in bottom stress prevents the propagation of the bottom crevasse. As time goes, the bottom stress increases while the surface crevasse grows. Then the bottom crevasse is able to propagate quickly through the entire ice thickness to cause calving as a result of the large difference between the water pressure and the ice overburden pressure.

Undercutting on the ice front is a common feature for glaciers (Rignot et al., 2010), whose influence on calving is still unclear. O'Leary and Christoffersen (2013) showed that undercutting leads to significant changes in the stress field near the ice front and enhances calving. Cook et al. (2014) argued, however, that the change in the stress field is only significant in diagnostic simulations and the undercutting influence is much smaller in prognostic simulations. Krug et al. (2015) also showed that undercutting has no effect on the glacier mass balance on annual time scales. Here, we find that undercutting does affect the stress field significantly near the ice front. It increases the surface stress and decreases the bottom stress just like the case of a shorter ice shelf and thus induces calving in a similar way. However, the influence is only for a short duration because of the viscous adjustment of the ice. If the undercutting is not large enough to produce calving in a short period of time, about $0.1 \mathrm{yr}$, it will have no impact on calving. If it is large and produces calving fast, then we find that undercutting enhances the propagation of crevasses. This conclusion reconciles the results of the previous studies and shows that the impact of undercutting depends on how long the ice shelf front remains undercut before the next calving.

\subsection{D modeling}

It would be of interest to generalize the present simulations to a 3D model. We do not think that the results of this study would be significantly changed, but a 3D model would provide a more realistic context for the model and is eventually needed to simulate the evolution of TG in the coming decades to centuries. A 3D model would include the impact of the eastern ice shelf, which is buttressed by a series of ice rumples (MacGregor et al., 2013). It would also include a more complete geometry of the bed with series of bumps and hollows. The grounding lines of HO and SSA may be more sensitive to changes in basal melt rate since they can retreat around subglacial bumps. In addition, the simulation of ice shelf rifts, not considered here but studied elsewhere (e.g. Larour et al. (2004)), would provide an additional context for the formation of tabular icebergs from the ice shelves in this region.

Since a FS 3D modeling of TG may not be possible at a high spatial resolution given our current computational constraints, we recommend a hybrid approach such as the one proposed by Seroussi et al. (2012), which uses FS around the grounding line region and employs simplified models in the surrounding regions. 
The Cryosphere Discuss., doi:10.5194/tc-2016-101, 2016

Manuscript under review for journal The Cryosphere

Published: 24 May 2016

(c) Author(s) 2016. CC-BY 3.0 License.

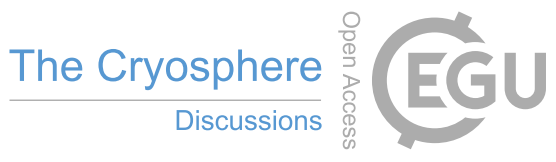

(c) (i)

\section{Conclusions}

In this study, we use a two-dimensional Full-Stokes model to study the grounding line dynamics and calving behavior of TG. We show that only FS is able to reproduce steady state conditions with basal melt rate similar to those deduced from remote sensing observations and only FS produces significant grounding line migration with enhanced basal melting. With

$5 \mathrm{HO}$ and SSA, the grounding line tends to advance from the initial position and is insensitive to realistic changes in basal melt rate. The explanation is that ice is pushed below hydrostatic equilibrium in that region and only FS is able to account for the non-hydrostatic conditions. In terms of calving dynamics, we show that FS combined with LEFM theory produces crevasses that match observations. We find that the non-hydrostatic conditions of ice near the grounding line significantly facilitate and explain the formation of deep crevasses. Shorter ice shelves, ice shelves with a significant amount of undercutting and ice shelves with surface crevasses appear more vulnerable to calving than long ice shelves, with vertical ice front and no surface crevasse. This work suggests that it is essential to use FS near the grounding line, to capture the grounding line dynamics correctly and to simulate the propagation of crevasses leading to calving events more realistically.

Acknowledgements. This work was carried out at the University of California Irvine and at California Institute of Technology's Jet Propulsion Laboratory under a contract with the Cryosphere Science Program of the National Aeronautics and Space Administration, grant NNX14AN03G. 
The Cryosphere Discuss., doi:10.5194/tc-2016-101, 2016

Manuscript under review for journal The Cryosphere

Published: 24 May 2016

(c) Author(s) 2016. CC-BY 3.0 License.

\section{References}

Benn, D. I., Warren, C. R., and Mottram, R. H.: Calving processes and the dynamics of calving glaciers, Earth Sci. Rev., 82, 143-179, doi:10.1016/j.earscirev.2007.02.002, 2007.

Blatter, H.: Velocity And Stress-Fields In Grounded Glaciers: A Simple Algorithm For Including Deviatoric Stress Gradients, J. Glaciol., 41, 333-344, 1995.

Cook, S., Rutt, I. C., Murray, T., Luckman, a., Zwinger, T., Selmes, N., Goldsack, a., and James, T. D.: Modelling environmental influences on calving at Helheim Glacier in eastern Greenland, Cryosphere, 8, 827-841, doi:10.5194/tc-8-827-2014, 2014.

Cuffey, K. M. and Paterson, W. S. B.: The Physics of Glaciers, 4th Edition, Elsevier, Oxford, 2010.

Depoorter, M. a., Bamber, J. L., Griggs, J. a., Lenaerts, J. T. M., Ligtenberg, S. R. M., van den Broeke, M. R., and Moholdt, G.: Calving fluxes and basal melt rates of Antarctic ice shelves., Nature, 502, 89-92, doi:10.1038/nature12567, 2013.

Docquier, D., Pollard, D., and Pattyn, F.: Thwaites Glacier grounding-line retreat: influence of width and buttressing parameterizations, J. Glaciol., 20, 305-313, doi:10.3189/2014JoG13J117, 2014.

Drouet, a. S., Docquier, D., Durand, G., Hindmarsh, R., Pattyn, F., Gagliardini, O., and Zwinger, T.: Grounding line transient response in marine ice sheet models, The Cryosphere, 7, 395-406, doi:10.5194/tc-7-395-2013, 2013.

Durand, G., Gagliardini, O., de Fleurian, B., Zwinger, T., and Le Meur, E.: Marine ice sheet dynamics: Hysteresis and neutral equilibrium, J. Geophys. Res., 114, 1-10, doi:10.1029/2008JF001170, 2009a.

Durand, G., Gagliardini, O., Zwinger, T., Le Meur, E., and Hindmarsh, R. C. A.: Full Stokes modeling of marine ice sheets: influence of the grid size, Ann. Glaciol., 50, 109-114, 2009b.

Favier, L., Gagliardini, O., Durand, G., and Zwinger, T.: A three-dimensional full Stokes model of the grounding line dynamics: effect of a pinning point beneath the ice shelf, The Cryosphere, 6, 101-112, doi:10.5194/tc-6-101-2012, 2012.

Fischer, M. P., Alley, R. B., and Engelder, T.: Fracture toughness of ice and firn determined from the modified ring test, Journal of Glaciology, 41, 383-394, 1995.

Fretwell, P., Pritchard, H. D., Vaughan, D. G., Bamber, J. L., Barrand, N. E., Bell, R., Bianchi, C., Bingham, R. G., Blankenship, D. D., Casassa, G., Catania, G., Callens, D., Conway, H., Cook, a. J., Corr, H. F. J., Damaske, D., Damm, V., Ferraccioli, F., Forsberg, R., Fujita, S., Gim, Y., Gogineni, P., Griggs, J. a., Hindmarsh, R. C. a., Holmlund, P., Holt, J. W., Jacobel, R. W., Jenkins, A., Jokat, W., Jordan, T., King, E. C., Kohler, J., Krabill, W., Riger-Kusk, M., Langley, K. a., Leitchenkov, G., Leuschen, C., Luyendyk, B. P., Matsuoka, K., Mouginot, J., Nitsche, F. O., Nogi, Y., Nost, O. a., Popov, S. V., Rignot, E., Rippin, D. M., Rivera, A., Roberts, J., Ross, N., Siegert, M. J., Smith, a. M., Steinhage, D., Studinger, M., Sun, B., Tinto, B. K., Welch, B. C., Wilson, D., Young, D. a., Xiangbin, C., and Zirizzotti, A.: Bedmap2: improved ice bed, surface and thickness datasets for Antarctica, The Cryosphere, 7, 375-393, 2013.

30 Glen, J. W.: The creep of polycrystalline ice, Proc. R. Soc. A, 228, 519-538, 1955.

Gogineni, P.: CReSIS Radar Depth Sounder Data, http://data.cresis.ku.edu/, 2012.

Holland, P. R., Jenkins, A., and Holland, D. M.: The response of ice shelf basal melting to variations in ocean temperature, J. CLim, 21, 2558-2572, doi:10.1175/2007JCLI1909.1, 2008.

Hughes, T.: The weak underbelly of the West Antarctic ice-Sheet, Journal of Glaciology, 27, 518-525, 1981.

Jacobs, S. S., Jenkins, A., Giulivi, C. F., and Dutrieux, P.: Stronger ocean circulation and increased melting under Pine Island Glacier ice shelf, Nature Geosci., 4, 519-523, doi:10.1038/NGEO1188, 2011. 
The Cryosphere Discuss., doi:10.5194/tc-2016-101, 2016

Manuscript under review for journal The Cryosphere

Published: 24 May 2016

(c) Author(s) 2016. CC-BY 3.0 License.

Jenkins, A., Dutrieux, P., Jacobs, S., McPhail, S., Perrett, J., Webb, A., and White, D.: Observations beneath Pine Island Glacier in West Antarctica and implications for its retreat, Nature Geosci., 3, 468-472, 2010.

Joughin, I., Smith, B. E., Howat, I. M., Floricioiu, D., Alley, R. B., Truffer, M., and Fahnestock, M.: Seasonal to decadal scale variations in the surface velocity of Jakobshavn Isbrae, Greenland: Observation and model-based analysis, J. Geophys. Res., 117, 1-20, doi:10.1029/2011JF002110, 2012.

Joughin, I., Smith, B. E., and Medley, B.: Marine ice sheet collapse potentially under way for the Thwaites Glacier Basin, West Antarctica., Science (New York, N.Y.), 344, 735-8, doi:10.1126/science.1249055, 2014.

Krug, J., Weiss, J., Gagliardini, O., and Durand, G.: Combining damage and fracture mechanics to model calving, The Cryosphere, 8 , 2101-2117, doi:10.5194/tc-8-2101-2014, 2014.

Krug, J., Durand, G., Gagliardini, O., and Weiss, J.: Modelling the impact of submarine frontal melting and ice mélange on glacier dynamics, The Cryosphere Discussions, 9, 183-221, doi:10.5194/tcd-9-183-2015, 2015.

Larour, E., Rignot, E., and Aubry, D.: Processes involved in the propagation of rifts near Hemmen Ice Rise, Ronne Ice Shelf, Antarctica, J. Glaciol., 50, 329-341, 2004.

Larour, E., Seroussi, H., Morlighem, M., and Rignot, E.: Continental scale, high order, high spatial resolution, ice sheet modeling using the Ice Sheet System Model (ISSM), J. Geophys. Res., 117, 1-20, doi:10.1029/2011JF002140, 2012.

Lenaerts, J. T. M., van den Broeke, M. R., van de Berg, W. J., van Meijgaard, E., Kuipers Munneke, P., and Munneke, P. K.: A new, highresolution surface mass balance map of Antarctica (1979-2010) based on regional atmospheric climate modeling, Geophys. Res. Lett., 39, 1-5, doi:10.1029/2011GL050713, 2012.

MacAyeal, D. R.: Large-scale ice flow over a viscous basal sediment: Theory and application to Ice Stream B, Antarctica, J. Geophys. Res., 94, 4071-4087, 1989.

MacGregor, J. A., Catania, G. A., Markowski, M. S., and Andrews, A. G.: Widespread rifting and retreat of ice-shelf margins in the eastern Amundsen Sea Embayment between 1972 and 2011, J. Glaciol., 58, 458-466, 2012.

MacGregor, J. A., Catania, G. A., Conway, H., Schroeder, D. M., Joughin, I., Young, D. A., Kempf, S. D., and Blankenship, D. D.: Weak bed control of the eastern shear margin of Thwaites Glacier, West Antarctica, Journal of Glaciology, 59, 900-912, doi:10.3189/2013JoG13J050, 2013.

Maule, C. F., Purucker, M. E., Olsen, N., and Mosegaard, K.: Heat Flux Anomalies in Antarctica Revealed by Satellite Magnetic Data, Science, 309, 464-467, 2005.

Morlighem, M., Rignot, E., Seroussi, H., Larour, E., Ben Dhia, H., and Aubry, D.: Spatial patterns of basal drag inferred using control methods from a full-Stokes and simpler models for Pine Island Glacier, West Antarctica, Geophysical Research Letters, 37, L14 502, 2010.

Morlighem, M., Rignot, E., Seroussi, H., Larour, E., Ben Dhia, H., and Aubry, D.: A mass conservation approach for mapping glacier ice thickness, Geophys. Res. Lett., 38, 1-6, doi:10.1029/2011GL048659, 2011.

Morlighem, M., Seroussi, H., Larour, E., and Rignot, E.: Inversion of basal friction in Antarctica using exact and incomplete adjoints of a higher-order model, J. Geophys. Res., 118, 1746-1753, doi:10.1002/jgrf.20125, 2013.

Mouginot, J., Rignot, E., and Scheuchl, B.: Sustained increase in ice discharge from the Amundsen Sea Embayment, West Antarctica, from 1973 to 2013, Geophys. Res. Lett., 41, 1-9, doi:10.1002/2013GL059069, 2014.

Nick, F. M., Vieli, A., Andersen, M. L., Joughin, I., Payne, A., Edwards, T. L., Pattyn, F., and van de Wal, R. S. W.: Future sea-level rise from Greenland's main outlet glaciers in a warming climate, Nature, 497, 235-238, 2013. 
The Cryosphere Discuss., doi:10.5194/tc-2016-101, 2016

Manuscript under review for journal The Cryosphere

Published: 24 May 2016

(c) Author(s) 2016. CC-BY 3.0 License.

Nowicki, S. M. J. and Wingham, D. J.: Conditions for a steady ice sheet-ice shelf junction, Earth Planet. Sci. Lett., 265, 246-255, doi:10.1016/j.eps1.2007.10.018, 2008.

Nye, J. F.: The distribution of stress and velocity in glaciers and ice-sheets, Proc. R. Soc. A, 239, 113-133, 1957.

O'Leary, M. and Christoffersen, P.: Calving on tidewater glaciers amplified by submarine frontal melting, Cryosphere, 7, 119-128, doi:10.5194/tc-7-119-2013, 2013.

Parizek, B. R., Christianson, K., Anandakrishnan, S., Alley, R. B., Walker, R. T., Edwards, R. a., Wolfe, D. S., Bertini, G. T., Rinehart, S. K., Bindschadler, R. a., and Nowicki, S. M. J.: Dynamic (in)stability of Thwaites Glacier, West Antarctica, J. Geophys. Res., 118, 1-18, doi:10.1002/jgrf.20044, 2013.

Pattyn, F.: A new three-dimensional higher-order thermomechanical ice sheet model: Basic sensitivity, ice stream development, and ice flow across subglacial lakes, J. Geophys. Res., 108, 1-15, doi:10.1029/2002JB002329, 2003.

Pritchard, H. D., Arthern, R. J., Vaughan, D. G., and Edwards, L. A.: Extensive dynamic thinning on the margins of the Greenland and Antarctic ice sheets, Nature, 461, 971-975, doi:10.1038/nature08471, 2009.

Rignot, E.: Evidence for rapid retreat and mass loss of Thwaites Glacier, West Antarctica, J. Glaciol., 47, 213-222, doi:10.3189/172756501781832340, 2001.

15 Rignot, E.: Changes in West Antarctic ice stream dynamics observed with ALOS PALSAR data, Geophys. Res. Lett., 35, 1-5, doi:10.1029/2008GL033365, 2008.

Rignot, E. and Jacobs, S. S.: Rapid bottom melting widespread near Antarctic ice sheet grounding lines, Science, 296, 2020-2023, doi:10.1126/science.1070942, 2002.

Rignot, E., Koppes, M., and Velicogna, I.: Rapid submarine melting of the calving faces of West Greenland glaciers, Nat. Geosci., 3, 187-191, doi:10.1038/NGEO765, 2010.

Rignot, E., Mouginot, J., and Scheuchl, B.: Ice Flow of the Antarctic Ice Sheet, Science, 333, 1427-1430, doi:10.1126/science.1208336, 2011.

Rignot, E., Jacobs, S., Mouginot, J., and Scheuchl, B.: Ice shelf melting around Antarctica, Science, 341, 266-270, doi:10.1126/science.1235798, 2013.

Rignot, E., Mouginot, J., Morlighem, M., Seroussi, H., and Scheuchl, B.: Widespread, rapid grounding line retreat of Pine Island, Thwaites, Smith and Kohler glaciers, West Antarctica from 1992 to 2011, Geophys. Res. Lett., in press, 2014.

Rist, M., Sammonds, P., Murrell, S., Meredith, P., Oerter, H., and Doake, C.: Experimental fracture and mechanical properties of Antarctic ice: preliminary results, Annals of Glaciology, 23, 284-292, 1996.

Rist, M. A., Sammonds, P. R., Oerter, H., and Doake, C. S. M.: Fracture of Antarctic shelf ice, J. Geophys. Res., 107, 1-13, doi:10.1029/2000JB000058, 2002.

Schoof, C.: Ice sheet grounding line dynamics: Steady states, stability, and hysteresis, J. Geophys. Res., 112, 1-19, doi:10.1029/2006JF000664, 2007.

Seroussi, H., Morlighem, M., Rignot, E., Larour, E., Aubry, D., Ben Dhia, H., and Kristensen, S. S.: Ice flux divergence anomalies on 79north Glacier, Greenland, Geophys. Res. Lett., 38, 1-5, 2011.

35 Seroussi, H., Ben Dhia, H., Morlighem, M., Rignot, E., Larour, E., and Aubry, D.: Coupling ice flow models of varying order of complexity with the Tiling Method, J. Glaciol., 58 (210), 776-786, doi:10.3189/2012JoG11J195, 2012.

Seroussi, H., Morlighem, M., Rignot, E., Khazendar, A., Larour, E., and Mouginot, J.: Dependence of century-scale projections of the Greenland ice sheet on its thermal regime, J. Glaciol., 59, 1024-1034, doi:10.3189/2013JoG13J054, 2013. 
The Cryosphere Discuss., doi:10.5194/tc-2016-101, 2016

Manuscript under review for journal The Cryosphere

Published: 24 May 2016

(c) Author(s) 2016. CC-BY 3.0 License.

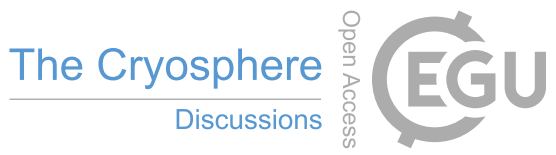

(c) (i)

Seroussi, H., Morlighem, M., Larour, E., Rignot, E., and Khazendar, A.: Hydrostatic grounding line parameterization in ice sheet models,

The Cryosphere, 8, 2075-2087, 2014.

Shepherd, A., Wingham, D., and Mansley, J.: Inland thinning of the Amundsen Sea sector, West Antarctica, Geophysical Research Letters, 29, 7-10, 2002.

5 Shepherd, A., Ivins, E. R., A, G., Barletta, V. R., Bentley, M. J., Bettadpur, S., Briggs, K. H., Bromwich, D. H., Forsberg, R., Galin, N., Horwath, M., Jacobs, S., Joughin, I., King, M. a., Lenaerts, J. T. M., Li, J., Ligtenberg, S. R. M., Luckman, A., Luthcke, S. B., McMillan, M., Meister, R., Milne, G., Mouginot, J., Muir, A., Nicolas, J. P., Paden, J., Payne, A. J., Pritchard, H., Rignot, E., Rott, H., Sø rensen, L. S., Scambos, T. a., Scheuchl, B., Schrama, E. J. O., Smith, B., Sundal, A. V., van Angelen, J. H., van de Berg, W. J., van den Broeke, M. R., Vaughan, D. G., Velicogna, I., Wahr, J., Whitehouse, P. L., Wingham, D. J., Yi, D., Young, D., and Zwally, H. J.: A reconciled estimate of ice-sheet mass balance., Science (New York, N.Y.), 338, 1183-9, 2012.

Spence, P., Griffie, S. M., England, M. H., Hogg, A. M., Saenko, O. A., and Jourdain, N. C.: Rapid subsurface warming and circulation changes of Antarctic coastal waters by poleward shifting winds, Geophys. Res. Lett., 41, 4601-4610, doi:10.1002/2014GL060613.Received, 2014.

Tinto, K. J. and Bell, R. E.: Progressive unpinning of Thwaites Glacier from newly identified offshore ridge: Constraints from aerogravity,

Geophys. Res. Lett., 38, 1-5, doi:10.1029/2011GL049026, 2011.

van der Veen, C. J.: Fracture mechanics approach to penetration of bottom crevasses on glaciers, Cold Reg. Sci. Technol., 27, 213-223, 1998a.

van der Veen, C. J.: Fracture mechanics approach to penetration of surface crevasses on glaciers, Cold Reg. Sci. Technol., 27, 31-47, 1998b. van der Veen, C. J. and Whillans, I. M.: Force budget: I. Theory and numerical methods, J. Glaciol., 35, 53-60, 1989.

Van der Veen, C. J. and Whillans, I. M.: Model experiments on the evolution and stability of ice streams, Annals of Glaciology, 23, 129-137, 1996.

Vieli, A. and Payne, A. J.: Assessing the ability of numerical ice sheet models to simulate grounding line migration, Journal of Geophysical Research, 110, F01 003, doi:10.1029/2004JF000202, 2005.

Vogel, C. R.: Computational Methods for Inverse Problems, Society for Industrial and Applied Mathematics, Philadelphia, PA, USA, 2002.

Weertman, J.: Stability of the junction of an ice sheet and an ice shelf, J. Glaciol., 13(67), 3-11, 1974. 
The Cryosphere Discuss., doi:10.5194/tc-2016-101, 2016

Manuscript under review for journal The Cryosphere

Published: 24 May 2016

(c) Author(s) 2016. CC-BY 3.0 License.

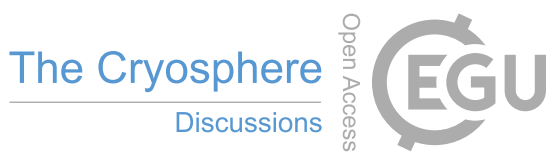

(c) (i)

Table 1. Experiments characteristics

\begin{tabular}{ccc}
\hline Experiment Set & Number of Experiments & Experiment Characteristics \\
\hline $\mathrm{Ma}$ & 4 & Control melt rate plus additional melt rate \\
$\mathrm{Mb}$ & 4 & Steady state melt rate plus additional melt rate \\
$\mathrm{Ca}$ & 11 & Current geometry with micro initial crevasses \\
$\mathrm{Cb}$ & 7 & 3 m initial surface crevasse \\
$\mathrm{Cc}$ & 7 & $4 \mathrm{~km}$ ice shelf \\
$\mathrm{Cd}$ & 4 & $2 \mathrm{~km}$ ice shelf \\
$\mathrm{Ce}$ & 7 & $4 \mathrm{~km}$ ice shelf with $400 \mathrm{~m}$ high, $400 \mathrm{~m}$ wide undercutting \\
\hline
\end{tabular}


The Cryosphere Discuss., doi:10.5194/tc-2016-101, 2016

Manuscript under review for journal The Cryosphere

Published: 24 May 2016

(c) Author(s) 2016. CC-BY 3.0 License.

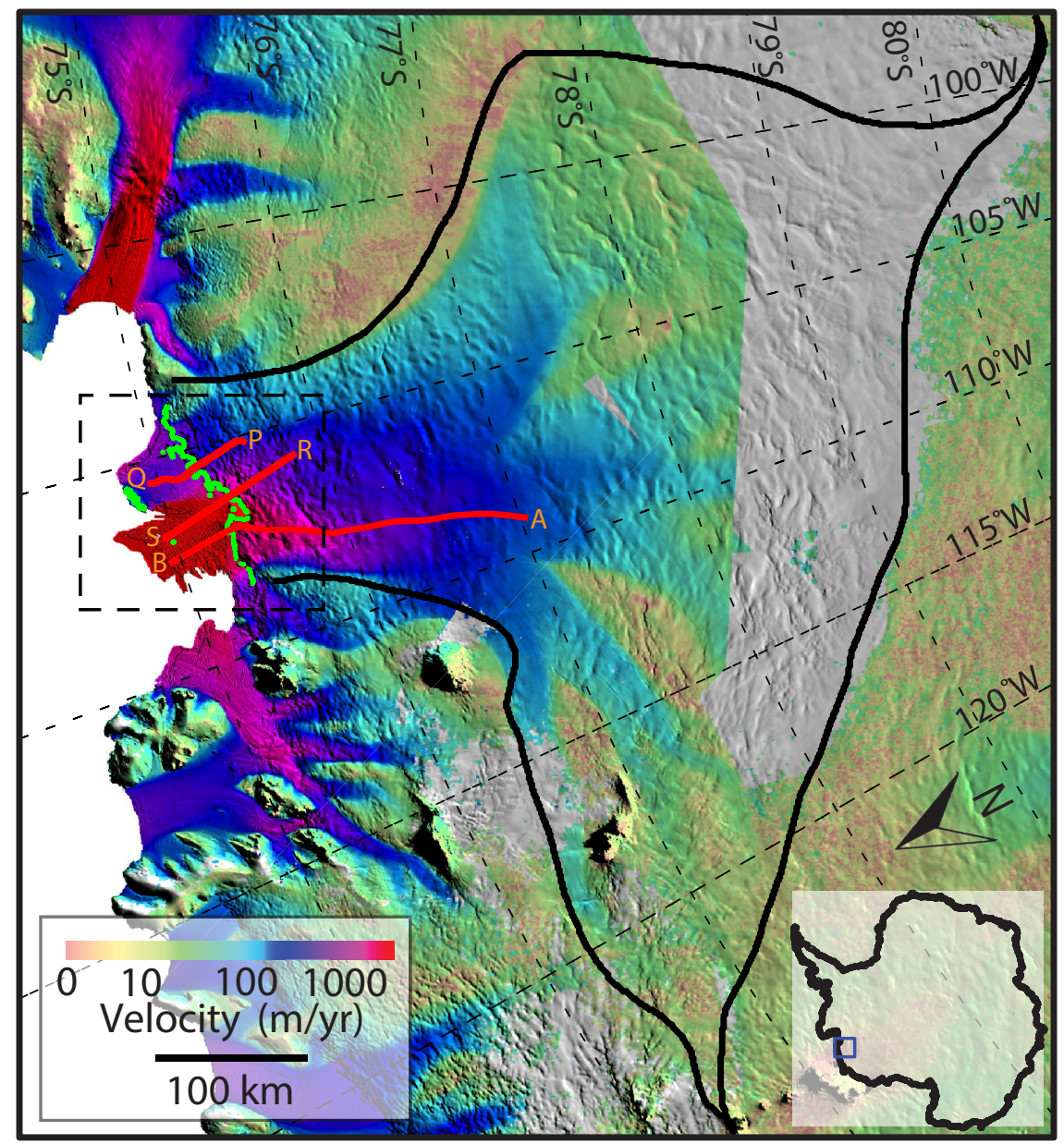

Figure 1. Velocity map of Thwaites Glacier (TG). The black contour is the drainage basin of TG. Dashed box is the region of the MODIS image in Fig. 2a, PQ and RS are the flight tracks of echogram in Fig. $2 b$ and 2c. AB is the selected flowline of this study. The green line is the grounding line of TG. 
The Cryosphere Discuss., doi:10.5194/tc-2016-101, 2016

Manuscript under review for journal The Cryosphere

Published: 24 May 2016

(c) Author(s) 2016. CC-BY 3.0 License.
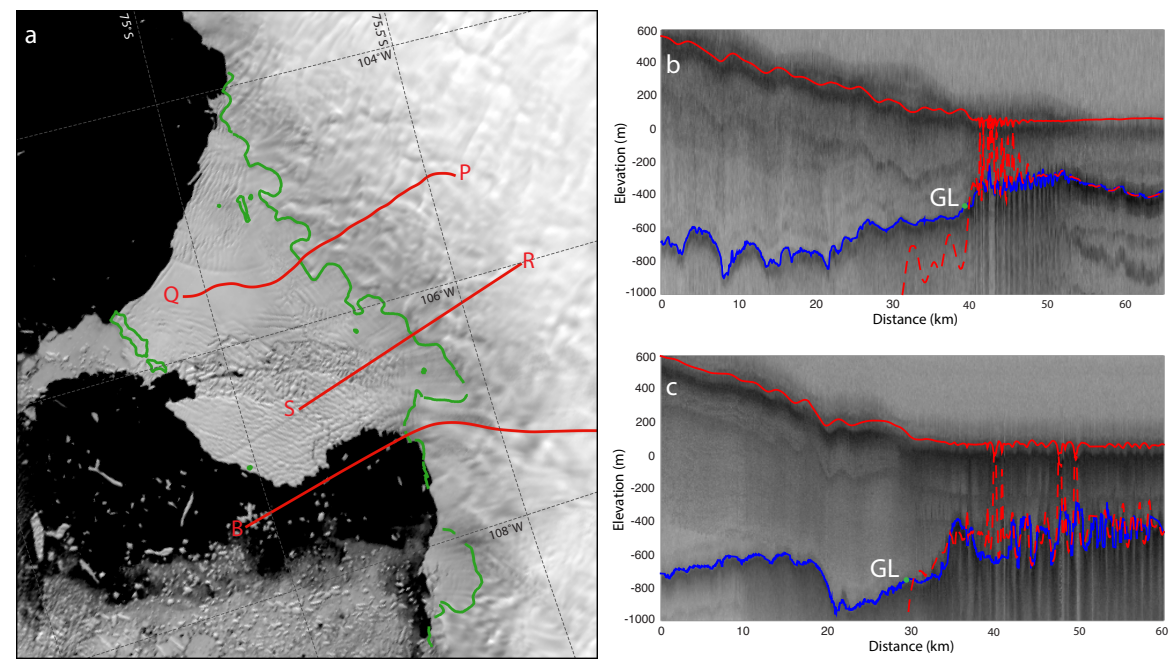

Figure 2. a) MODIS image of TG on Jan.15, 2013. The green line (a) and dots (b and c) are the grounding line positions. b) Echogram of flight track PQ on Nov.02, 2009. c) Echogram of flight track RS on Nov.19, 2011. The red solid lines are ice surface elevation measured from Airborne Topographic Mapper (ATM) and the red dashed lines are bed elevation calculated from hydrostatic equilibrium. The blue line is the elevation of ice bottom measured from ice radar sounder.

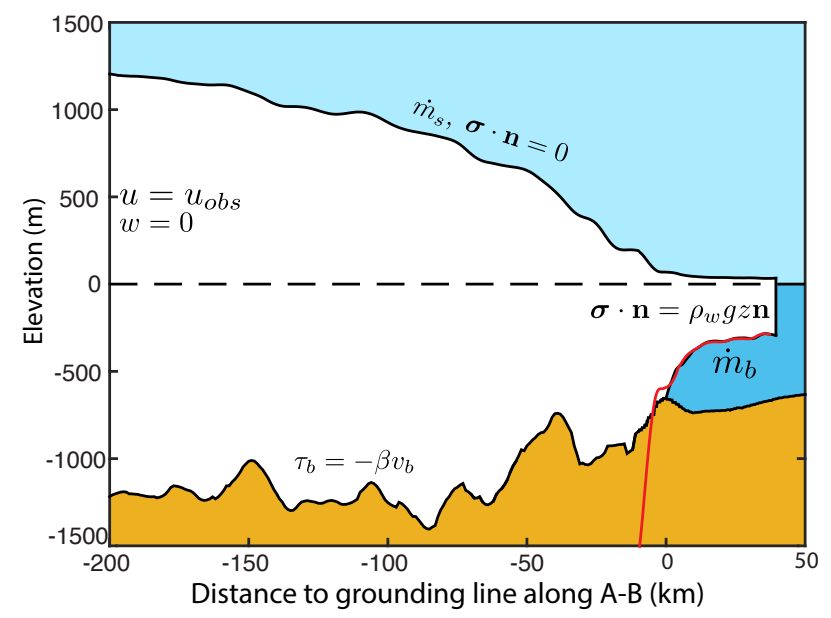

Figure 3. Geometry of flowline A-B in Fig. 1 and boundary conditions of the model. The red line is the hydrostatic bed calculated from surface elevation 
The Cryosphere Discuss., doi:10.5194/tc-2016-101, 2016

Manuscript under review for journal The Cryosphere

Published: 24 May 2016

(c) Author(s) 2016. CC-BY 3.0 License.

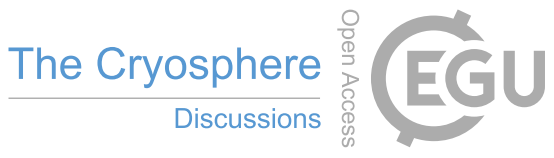

(c) (i)

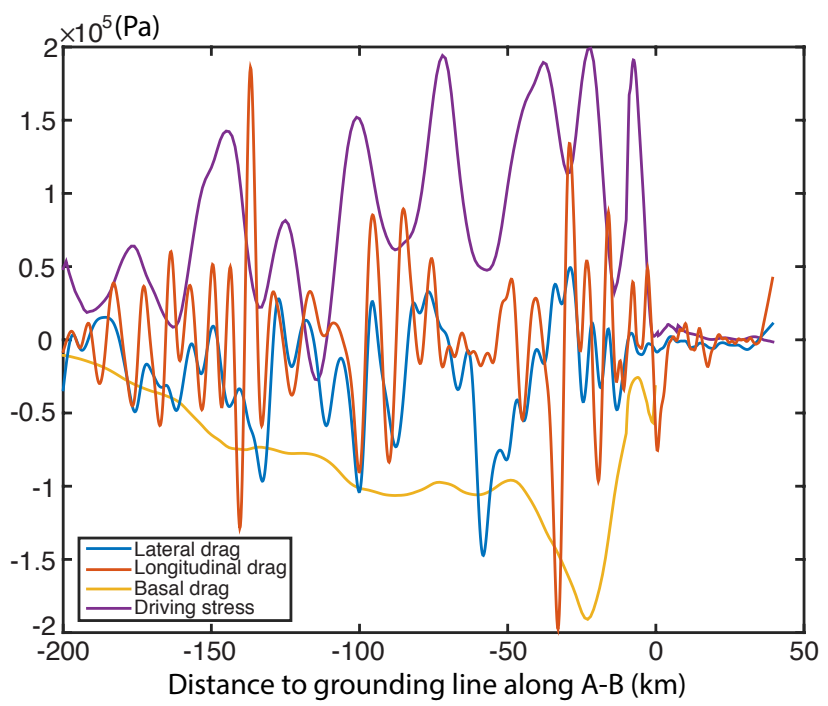

Figure 4. Comparison of lateral drag, longitudinal drag, basal drag and driving stress along flowline A-B over a length scale of $5 \mathrm{~km}$.
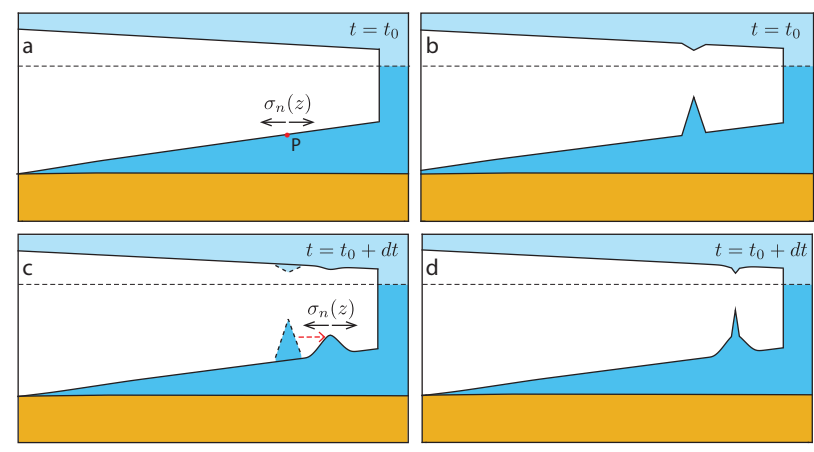

Figure 5. Algorithm for the combination of ISSM and the LEFM model. 
The Cryosphere Discuss., doi:10.5194/tc-2016-101, 2016

Manuscript under review for journal The Cryosphere

Published: 24 May 2016

(c) Author(s) 2016. CC-BY 3.0 License.

(c) (i)
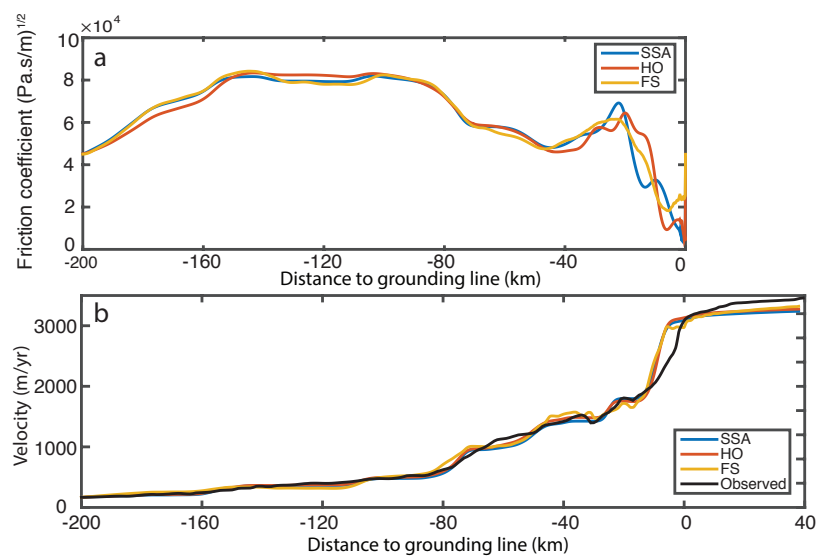

Figure 6. a) Friction coefficient inferred with all three models. b) Comparison of modeled velocity and observed surface velocity.

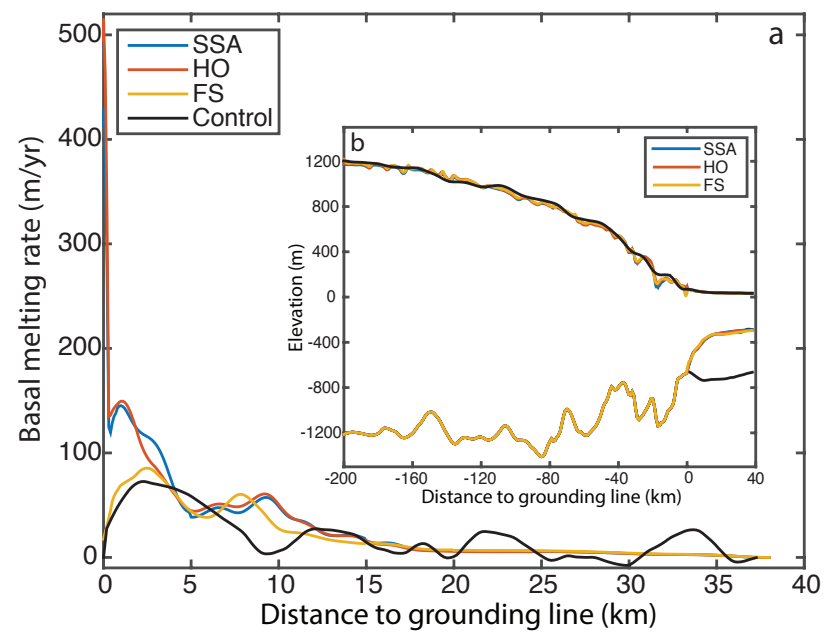

Figure 7. a) Basal melt rate required to achieve steady state solution at current geometry for all three models. b) Flowline geometry of all three models at the end of the simulations. Black lines are the current observed geometry. 
The Cryosphere Discuss., doi:10.5194/tc-2016-101, 2016

Manuscript under review for journal The Cryosphere

Published: 24 May 2016

(c) Author(s) 2016. CC-BY 3.0 License.

\section{(c) (1)}
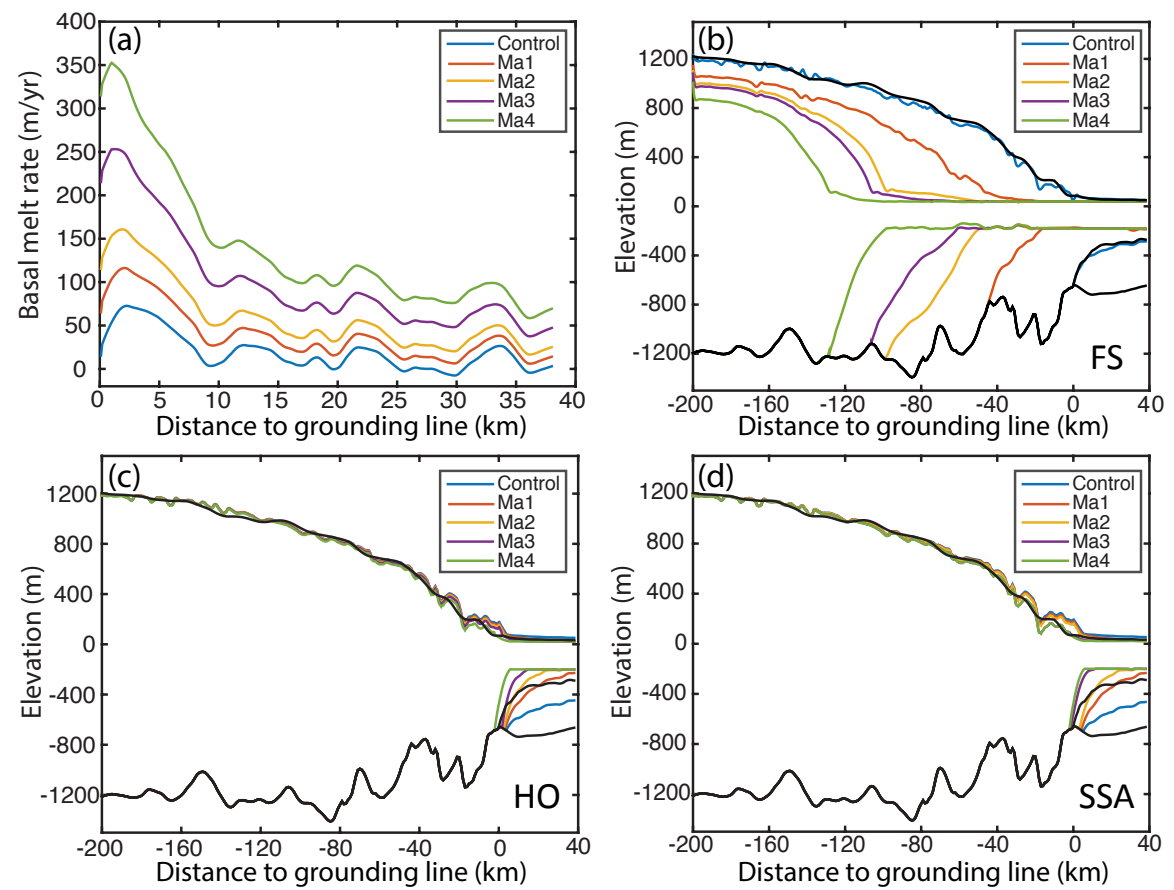

Figure 8. Evolution of flowline geometry of Exp. Ma1-Ma4. a) Basal melt rate for each experiment. b) Final geometry of FS experiments. c) Final geometry of HO experiments. d) Final geometry of SSA experiments.
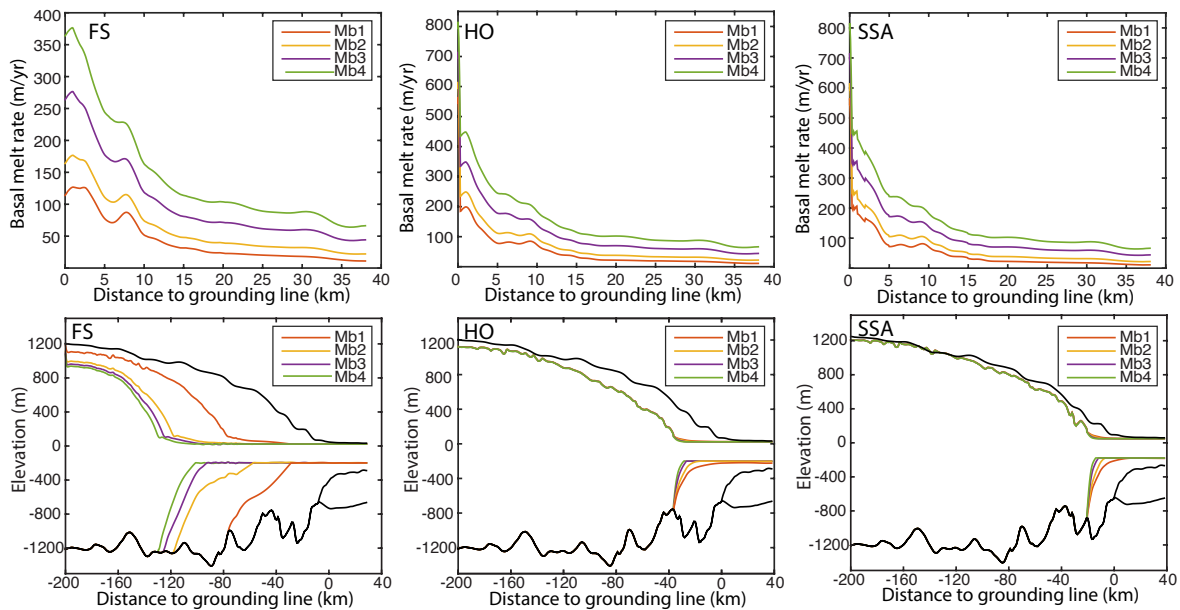

Figure 9. Evolution of flowline geometry for Exp. Mb1-Mb4. Upper panels are the basal melt rate for each experiment and lower panels are the final geometry profiles for FS, HO and SSA, respectively. 
The Cryosphere Discuss., doi:10.5194/tc-2016-101, 2016

Manuscript under review for journal The Cryosphere

Published: 24 May 2016

(c) Author(s) 2016. CC-BY 3.0 License.

\section{(c) (1)}

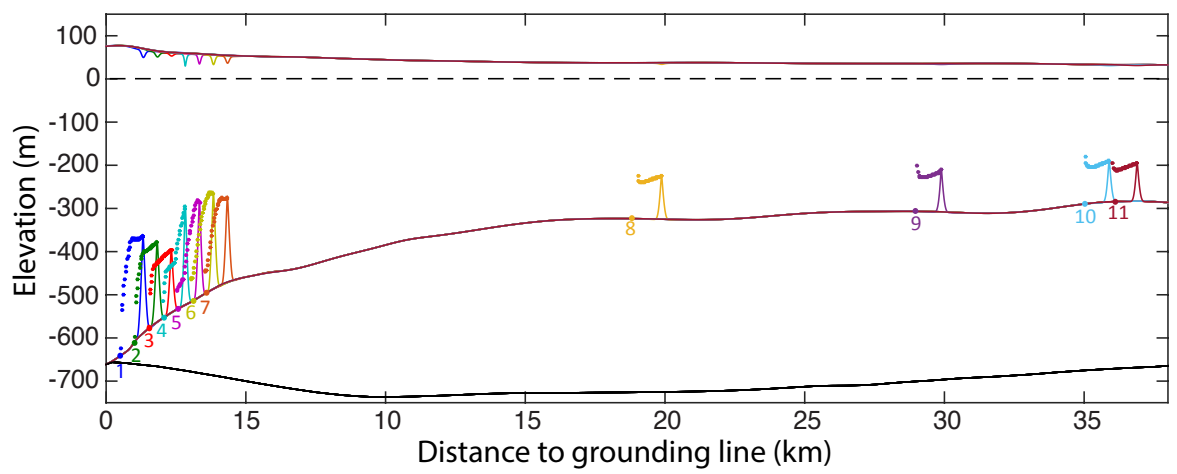

Figure 10. Crevasse propagation of Exp. Ca1-Ca11 with FS. Each color corresponds to one initial crevasse position, indicated by the number. The solid lines are final crevasse shape and the dotted lines are the evolution of the tip of bottom crevasses.
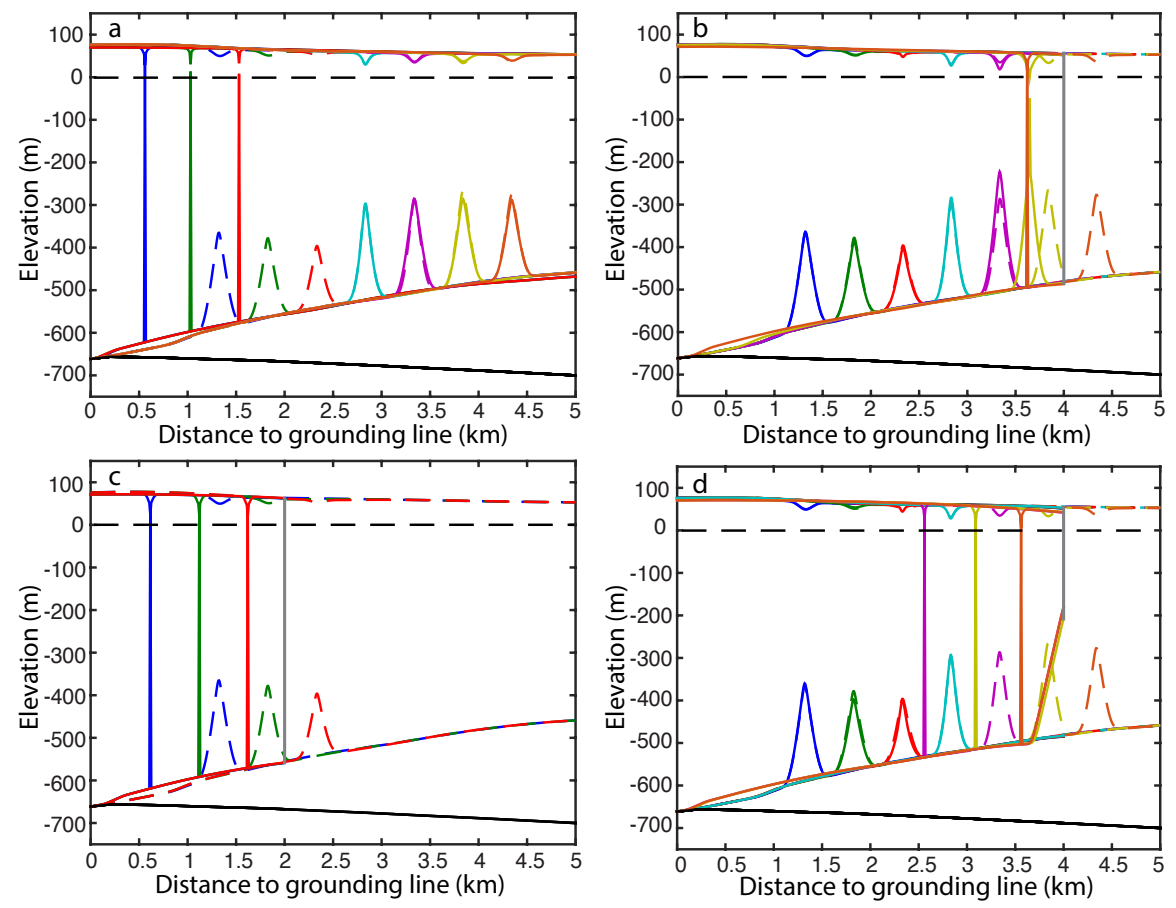

Figure 11. Crevasse propagation in the grounding line region. In each panel, dashed lines are the final crevasses shape from the initial geometry (Exp. Ca1-Ca11). Solid lines are final crevasses shape with a) $3 \mathrm{~m}$ initial surface crevasse (Exp. Cb1-Cb7), b) 4 km ice shelf (Exp. Cc1-Cc7), c) $2 \mathrm{~km}$ ice shelf (Exp. Cd1-Cd3) and d) $4 \mathrm{~km}$ ice shelf with a $400 \mathrm{~m}$ wide and $400 \mathrm{~m}$ high undercutting ice front (Exp. Ce1-Ce7). The grey lines in $\mathrm{b}, \mathrm{c}$ and $\mathrm{d}$ are the ice front positions. 